\title{
1-Phosphatidylinositol 4,5-Bisphosphate Phosphodiesterase Delta-3
}

National Cancer Institute

\section{Source}

National Cancer Institute. 1-Phosphatidylinositol 4,5-Bisphosphate Phosphodiesterase

Delta-3. NCI Thesaurus. Code C116274.

1-phosphatidylinositol 4,5-bisphosphate phosphodiesterase delta-3 (789 aa, $\sim 89 \mathrm{kDa}$ ) is encoded by the human PLCD3 gene. This protein is involved in the generation of second messenger molecules from phosphoinositides. 